\title{
Pengolahan Data Nilai Siswa Pada SMP Negeri 7 Kota Metro Berbasis WEB
}

\author{
Dedi Irawan ${ }^{(1)}$ I Putu Arya Aryanto ${ }^{(2)}$ \\ Jurusan Ilmu Komputer, Fakultas Ilmu Komputer,Universitas Muhammadiyah Metro \\ Jl.Gatot Subroto No.100 Yosodadi Kota Metro, Telpon :(0725)42445-Fax(0725)42454 \\ E-mail : dedimti@gmail.com
}

\begin{abstract}
Abstrak
Penelitian ini merupakan hasil dari analisis dan observasi yang penulis lakukan terhadap sistem informasi yang sedang berjalan dan hasil perancangan yang baru dari website sebagai sarana evaluasi kegiatan data nilai siswa di smp negeri 7 kota metro. Peneliti menggunakan metode studi lapangan yaitu: pengamatan, wawancara, dan dokumentasi. Studi pustaka dengan mencari dan mempelajari sistem kerja yang berkaitan dengan penelitian. Tujuan dari penelitian ini adalah untuk merancang sistem informasi pengolahan data nilai siswa pada Sekolah Menengah Pertama SMP Negeri 7 Kota Metro yang beralamat di J1. Stadion Tejosari Kec. Metro Barat. Alasan perancangan ini adalah karena Pihak sekolah masih menggunakan proses pencatatan pada microsoft excel dalam mengolah nilai sehingga kurang efektif dan efisien dalam proses pengolahan data siswa. Dari permasalahan yang ada maka penyelesaiannya yaitu dengan menggunakan bahasa pemegroman php dan dalam pengembangannya menggunakan sistem berbasis web. Hasil yang didapat dengan menggunakan metode tersebut adalah data yang terintegrasi. Sehingga dalam proses pengolahan data akan semakin terorganisir dengan baik. Kata Kunci : Sistem Informasi, Nilai, PHP.
\end{abstract}

Kata kunci : Pengolahan Data, Nilai Siswa, SMP N 7 Metro 


\section{PENDAHULUAN}

Perkembangan teknologi yang semakin maju pada saat ini mamacu manusia untuk berpikir lebih maju. Di dorong oleh perkembangan teknologi, manusia menginginkan segala sesuatu dilaksanakan dengan mudah, cepat dan akurat. Dengan majunya perkembangan zaman kemungkinan, pemakaian komputer sering digunakan sebagai alat bantu dalam peranan teknologi, mengingat semakin rumitnya proses pengelolaan data. Untuk mempermudah proses-proses yang dilakukan, maka dibuat suatu perancangan sistem yang mengacu pada pengelolaan data secara sistematis dengan tujuan agar para pemakai dapat dengan mudah, cepat, tepat dan akurat. Sistem informasi data nilai siswa adalah suatu masalah yang rumit dan harus diteliti. Dengan cara bagaimana merancang sistem informasi data nilai siswa menggunakan suatu program komputer yang digunkan untuk memudahkan para pegawai dan guru dalam mengolah data nilai siswa secara lebih cepat dan efesien. Sehingga menghasilkan informasi yang cepat dan akurat dalam mencari data-data siswa, maka dari itu dibutuhkan suatu media komputer sebagai alat yang membantu manusia untuk bekerja lebih cepat dan menghasilkan informasi yang akurat. Teknologi informasi telah mengubah manusia dalam segala aspek kehidupan, seperti pada saat penyimpanan data, pengolah data serta pencarian informasi, secara tidak langsung dapat dikatakan semua serba terkomputerisasi. Pengelolaan data nilai siswa di SMP Negeri 7 Kota Metro merupakan salah satu komponen yang penting dalam mewujudkan suatu sistem informasi disekolah, pengelolaan data secara manual, mempunyai banyak kelemahan, selain membutuhkan waktu lama keakurasian data juga kurang dapat diterima karena kemungkinan kesalahan sangat besar. Dengan didukungan teknologi informasi yang akan dibuat, harapkan pekerjaan pengelolaan data dapat digantikan oleh suatu sistem informasi dengan menggunakan teknologi komputer. SMP Negeri 7 kota Metro adalah salah satu sekolah yang berada di Kota Metro. Beralamat di Jl. Stadion 24 Kelurahan Tejosari Kecamatan Metro Timur. Sejarah berdirinya SMP Negeri 7 Kota Metro pada tanggal 17 januari 1959 kemudian pada tahun 1963 berganti nama menjadi Sekolah Teknik Persiapan Negeri, Berdasarkan SK Menteri Pendidikan dan Kebudayaan RI No:067/0/94/ tanggal 2 April 1994 alih fungsi menjadi menjadi SMP Negeri 7 Kota Metro yang dipimpin oleh ibu Repiyati, S.Pd. Sama dengan SMP Negeri pada umumnya di indonesia masa pendidikan sekolah di SMP Negeri 7 Kota Metro ditempuh dalam waktu tiga tahun pelajaran, mulai dari Kelas VII Vlll dan IX. Hingga kini sekolah masih merupakan sekolah yang meluluskan lulusan-lulusan yang berpestasi baik bidang akademik maupun non akademik. Gedung semakin baik sebagai fasilitas penunjang pembelajaran dan kini sekolah ini menjadi sekolah yang besar. SMP Negeri 7 Metro adalah sebuah sekolah menengah pertama yang menyelenggarakan pendidikan formal dengan jumlah peserta didik sebanyak 618 orang yang tersebar ke 22 kelas. Sebagai institusi penyelenggara pendidikan, tingkat kompetensi peserta didik menjadi hal yang paling penting sebagai bagian dari proses penilaian. Salah satu bentuk dari proses penilaian tersebut adalah dengan melihat aktifitas siswa dalam.

\section{KAJIAN PUSTAKA DAN LANDASAN TEORI}




\subsection{Pengertian Website}

World Wide Web atau WWW atau juga dikenal dengan WEB adalah salah satu layanan yang didapat oleh pemakai computer yang terhubung ke internet. Web ini menyediakan informasi bagi pemakai computer yang terhubung ke internet dari sekedar informasi "sampah" atau informasi yang tidak berguna sama sekali sampai informasi yang serius: dari informasi yang gratisan sampai informasi yang komersial. Website atau situs dapat diartikan sebagai kumpulan halamanhalaman yang digunakan untuk menampilkan informasi teks, gambar diam atau gerak, animasi, suara, dan atau gabungan dari semuanya itu baik yang bersifat statis maupun dinamis yang membentuk satu rangkaian bangunan yangsaling terkait dimana masing-masing dihubungkan dengan jaringan (hyperlink). Gregorius ( 2000: 30 ) Pengertian web menurut Gregorius adalah kumpulan halaman web yang saling terhubung dan file-filenya saling terkait. Web terdiri dari page atau halaman, dan kumpulan halaman dinamakan homepage. Hakim Lukmanul ( 2004 ) Pengertian web site menurut Hakim Lukmanul adalah fasilitas internet yang menghubungkan dokumen dalam lingkup lokal maupun jarak jauh. Dokumen pada website disebut dengan web page dan link dalam website memungkinkan pengguna bisa berpindah dari satu page ke page lain ( hyper text ), baik diantara page yang disimpan dalam server yang sama maupun server diseluruh dunia. Pages diakses dan dibaca melalui browser seperti Netscape Navigator, Internet Explorer, Mozila Firefox, Google Chrome dan aplikasi browser lainnya.

\subsection{Pengertian Perancangan}

Kenneth dan Jane (2006:G12) menjelaskan bahwa perancangan sistem adalah kegiatan merancang detil dan rincian dari sistem yang akan dibuat sehingga sistem tersebut sesuai dengan requirement yang sudah ditetapkan dalam tahap analisa sistem. Lebih lanjut O'Brien dan Marakas (2009:639) menjelaskan bahwa perancangan sistem adalah sebuah kegiatan merancang dan menentukan cara mengolah sistem informasi dari hasil analisa sistem sehingga dapat memenuhi kebutuhan dari pengguna termasuk diantaranya perancangan user interface, data dan aktivitas proses. Menurut Bentley dan Whitten (2009:160) melalui buku yang berjudul "system analysis and design for the global enterprise" juga menjelaskan bahwa perancangan sistem adalah teknik pemecahan masalah dengan melengkapi komponen-komponen kecil menjadi kesatuan komponen sistem kembali ke sistem yang lengkap. Teknik ini diharapkan dapat menghasilkan sistem yang lebih baik. Menurut bin Ladjamudin (2005:39) "Perancangan adalah tahapan perancangan (design) memiliki tujuan untuk mendesain sistem baru yang dapat menyelesaikan masalah-masalah yang dihadapi perusahaan yang diperoleh dari pemilihan alternative sistem yang terbaik.

\subsection{Pengertian Sistem Informasi}

Menurut Gordon B. Davis (1991: 91) Sistem informasi adalah suatu sistem yang menerima input atau masukan data dan instruksi, mengolah data sesuai dengan instruksi dan mengeluarkan hasilnya. Menurut John F. Nash (1995: 8) Sistem informasi adalah sistem Informasi adalah kombinasi dari manusia, fasilitas atau alat teknologi, media, prosedur dan pengendalian yang ditujukan untuk 
mengatur jaringan komunikasi yang penting, proses transaksi tertentu dan rutin, membantu manajemen dan pemakai internet dan ekstern dan menyediakan dasar untuk pengambilan keputusan yang tepat. Menurut Kertahadi (2007) Sistem informasi adalah alat untuk menyajikan informasi sedemikian rupa sehingga bermanfaat bagi penerimanya. Tujuannya adalah untuk memberikan informasi dalam perencanaan, memulai, pengorganisasian, operasional sebuah perusahaan yang melayani sinergi organisasi dalam proses mengendalikan pengambilan keputusan. Pengertian Pengelohan Menurut Balderton (dalam Adisasmita, 2011:21), istilah pengelolaan sama dengan manajemen yaitu menggerakan, mengorganisasikan, dan mengarahkan usaha manusia untuk memanfaatkan secara efektif material dan fasilitas untuk mencapai suatu tujuan. Menurut Adisasmita (2011:22) mengemukakan bahwa, Pengelolaan bukan hanya melaksanakan suatu kegiatan, akan tetapi merupakan rangkaian kegiatan yang meliputi fungsifungsi manajemen, seperti perencanaan, pelaksanaan, dan pengawasan untuk mencapai tujuan secara efektif dan efisien. Menurut T.Hani Handoko (1997:8) pengelolaan adalah proses yang membantu merumuskan suatu kebijakan dan tujuan organisasi atau proses yang memberikan pengawasan pada suatu yang terlibat dalam pelaksanaan dan pencapaian tujuan.

\subsection{Pengertian Data}

Menurut Inmon (2005:493), data adalah sebuah rekaman dari fakta- fakta, konsep-konsep, atau instruksi-instruksi pada media penyimpanan untuk komunikasi perolehan, dan pemrosesan dengan cara otomatis dan presentasi sebagai informasi yang dapat dimengerti oleh manusia. Menurut McLeod dan Schell (2007:9), data adalah kumpulan fakta dan gambaran yang secara umum tidak dapat digunakan karena ukuran yang besar dan belum diolah. Menurut Turban (2010, p41), data adalah deskripsi dasar dari benda, peristiwa, aktivitas dan transaksi yang direkam, dikelompokkan, dan disimpan tetapi belum terorganisir untuk menyampaikan arti tertentu.

\subsection{Pengertian Nilai Siswa}

Sebagaimana tertuang dalam Pasal 63 Peraturan Pemerintah No. 19 Tahun 2005, standar penilaian adalah standar penilaian hasil belajar yang di lakukan oleh pendidik, satuan pendidikan, dan pemerintah. Penilaian hasil belajar ini dilakukan secara berkesinambungan untuk memantau proses, kemajuan, dan perbaikan hasil dalam bentuk ulangan harian, ulangan tengah semester, ulangan akhir semester. Penilaian yang menekankan pada proses ini bertujuan untuk menilai pencapaian kompetensi peserta didik, yang digunakan sebagai bahan penyusunan laporan kemajuan belajar dan memperbaiki proses pembelajaran. Dari pengertian diatas dapat disimpulkan bahwa Nilai dapat di artikan dalam 5 hal yaitu harga dalam taksiran, harga sesuatu, angka kepandaian, kadar/mutu dan sifat-sifat yang penting. Menurut Antony Giddens (1995) "Nilai adalah gagasan-gagasan yang dimiliki oleh seseorang atau kelompok tentang apa yang dikehendaki, apa yang layak, dan apa yang baik atau buruk". Menurut Fraenkel (1977) " $A$ Value is an idea- a concept about-what some thinks is important in life ( nilai 
adalah ide atau konsep tentang apa yang dipikirkan seseorang atau dianggap penting oleh seseorang). Kluckhohn (mulyana, 2004:1) Nilai adalah konsepsi (tersurat atau tersirat, yang sifatnya membedakan individu atau ciri-ciri kelompok) dari apa yang diinginkan, yang memengaruhi tindakan pilihan terhadap cara, tujuan antar dan tujuan akhir. Defenisi ini berimplikasi terhadap pemaknaan nilai-nilai budaya, seperti yang diungkapkan oleh Brameld dalam bukunya tentang landasan-landasan budaya pendidikan.

\subsection{Bahasa Pemograman (WEB)}

PHP adalah kependekan dari PHP: Hypertext Preprocessor. Sedangkan pengertian PHP adalah bahasa pemrograman web server-side yang bersifat open source. PHP merupakan script yang terintegrasi dengan $H T M L$ dan berada pada server (server side HTML embedded scripting). PHP adalah script yang digunakan untuk membuat halaman website yang dinamis. Dinamis berarti halaman yang akan ditampilkan dibuat saat halaman itu diminta oleh client. Mekanisme ini menyebabkan informasi yang diterima client selalu yang terbaru atau up to date. Semua script PHP dieksekusi pada server di mana script tersebut dijalankan.

\subsection{Pengertian Sublime Text}

Sublime Text adalah aplikasi editor untuk kode dan teks yang dapat berjalan diberbagai platform operating system dengan menggunakan teknologi Phyton API. Terciptanya aplikasi ini terinspirasi dari aplikasi Vim, Aplikasi ini sangatlah fleksibel dan powerfull. Fungsionalitas dari aplikasi ini dapat dikembangkan dengan menggunakan sublime-packages. Sublime Text bukanlah aplikasi open source dan juga aplikasi yang dapat digunakan dan didapatkan secara gratis, akan tetapi beberapa fitur pengembangan fungsionalitas (packages) dari aplikasi ini merupakan hasil dari temuan dan mendapat dukungan penuh dari komunitas serta memiliki linsensi aplikasi gratis.

\subsection{MySql}

MySQL adalah sebuah perangkat lunak sistem manajemen basis data SQL (bahasa Inggris: database management system) atau DBMS yang multialur, multipengguna, dengan sekitar 6 juta instalasi di seluruh dunia. MySQL AB membuat MySQL tersedia sebagai perangkat lunak gratis di bawah lisensi GNU General Public License (GPL), tetapi mereka juga menjual di bawah lisensi komersial untuk kasus-kasus di mana penggunaannya tidak cocok dengan penggunaan GPL.

\section{METODE}

Metode pengumpulan data adalah kesatuan metode- metode, prosedur, konsep-konsep dalam memperoleh data guna menyusun Tugas Akhir. Penulis menggunakan metode - metode yaitu sebagai berikut:

a. Studi Lapangan

Untuk mendapatkan data, penulis melakukan studi lapangan dengan menggunakan teknik:

1. Pengamatan (Observasi)

Yaitu metode pengumpulan data dengan cara melakukan pengamatan secara langsung sistem yang sedang berjalan di SMP Negeri 7 Kota Metro.

2. Wawancara (Interview) 
Yaitu metode pengumpulan data dengan cara melakukan komunikasi dan tanya jawab secara langsung dengan waka siswa unyah sanjaya S.Pd" sebagai kepala guru bimbingan konseling.

3. Dokumentasi (Dokumentation) Dokumentasi adalah metode pengumpulan data dengan cara mengumpulkan dokumen arsip yang dibutuhkan untuk penelitian.

b. Studi Pustaka

Studi pustaka adalah penelitian dengan pengumpulan data dan informasi yang ada di SMP Negeri 7 Kota Metro. Untuk menambah beberapa hal yang tidak penulis dapat dalam study lampangan. Study pustaka penulis melakukan dengan cara mengumpulkan data dengan membaca buku-buku dan memperlajari literatur yang berkaitan dengan masalah yang dihadapi.

\section{HASIL DAN PEMBAHASAN}

\subsection{Perancangan Diagram Kontex}

Diagram kontek merupakan arus data suatu sistem pengolahan data yang digambarkan dalam bentuk diagram.

Diagram kontek berguna untuk mengetahui arus data yang terjadi dalam suatu sistem pengolahan data.

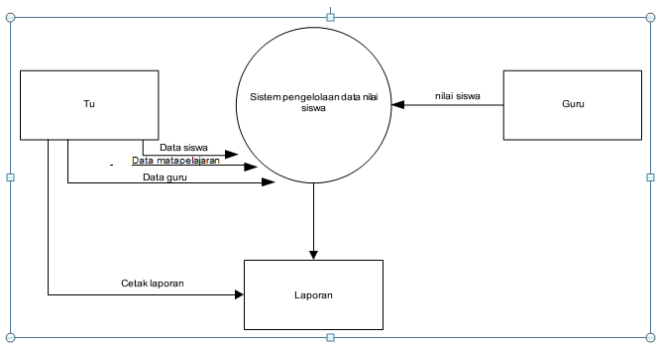

\subsection{Perancangan DFD}

DFD merupakan alat yang digunakan pada metodologi pengembangan sistem yang berstruktur Strucured Analysis and Design. DFD sering digunakan secara logika tanpa pertimbangan lingkungan fisik dimana data tersebut mengalir atau data tersebut akan disimpan.

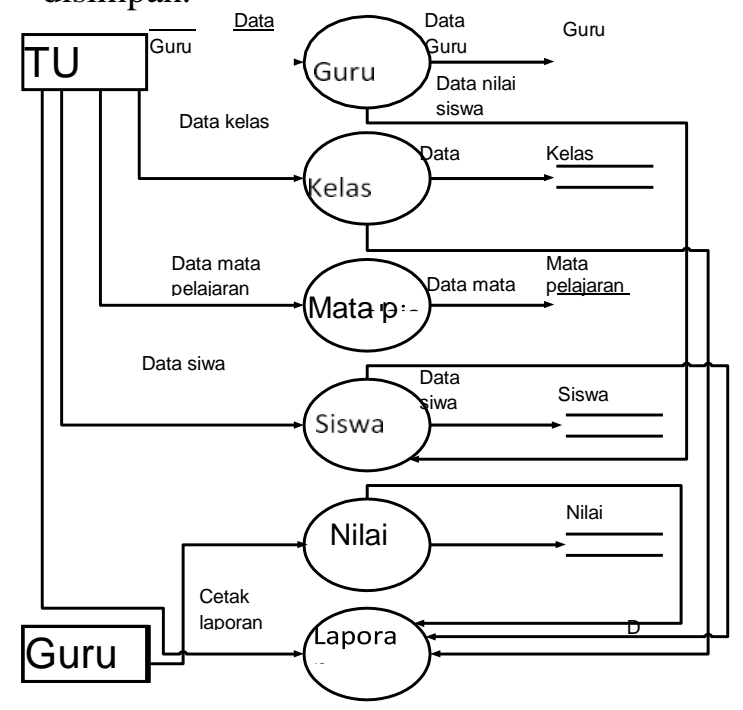




\subsection{Perancangan Sistem Secara} Penulisan
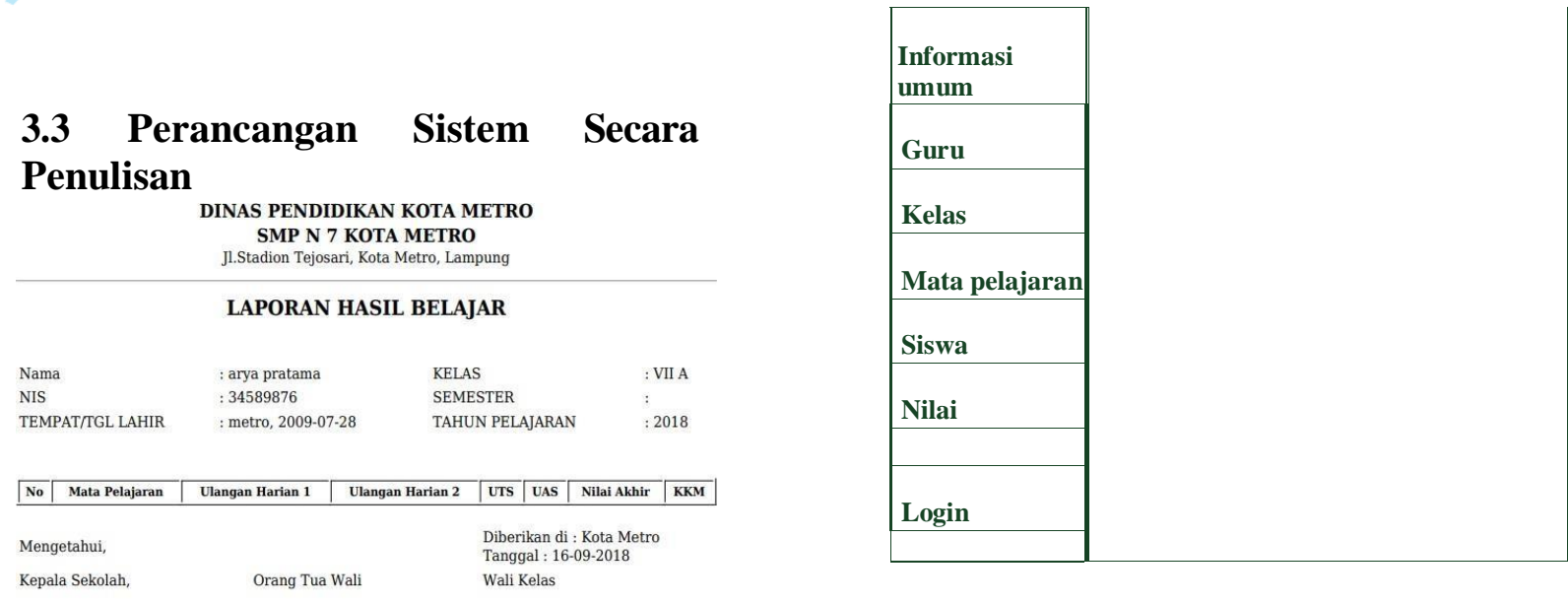

LOGIN ADMIN

admin

.....

Perancangan form tampilan

loginadalah sub menu

login.

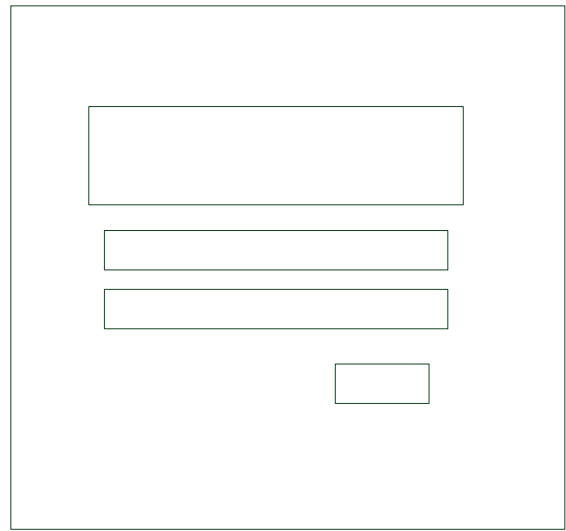

Perancangan form tampilan home adalah sub menu home/halaman utama .

\begin{tabular}{|l|l|}
\hline \multicolumn{2}{|l|}{ ADMINITRATOR LOGO } \\
\hline $\begin{array}{l}\text { Home } \\
\text { Dashboard }\end{array}$ & \\
\hline Home $>$ Home \\
\hline Dashboard & \\
\hline
\end{tabular}

\subsection{Tampilan Halaman Home}

Tampilan halaman menu utama berfungsi sebagai tampilan awal web pengelolahan data nilai siswa. 


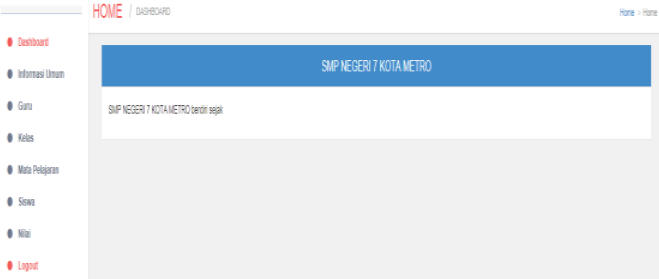

\subsection{Tampilan halaman guru}

Tampilan From Input Data guru Tampilan ini berfungsi sebagai tempat untuk memasukan data guru.

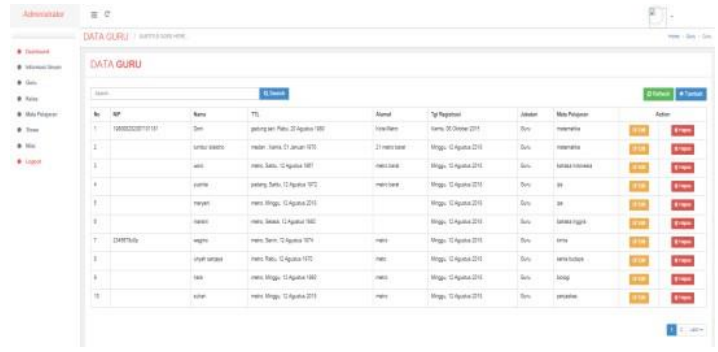

Tampilan From Input Data kelas Tampilan ini berfungsi sebagai tampat untuk memasukan data kelas.

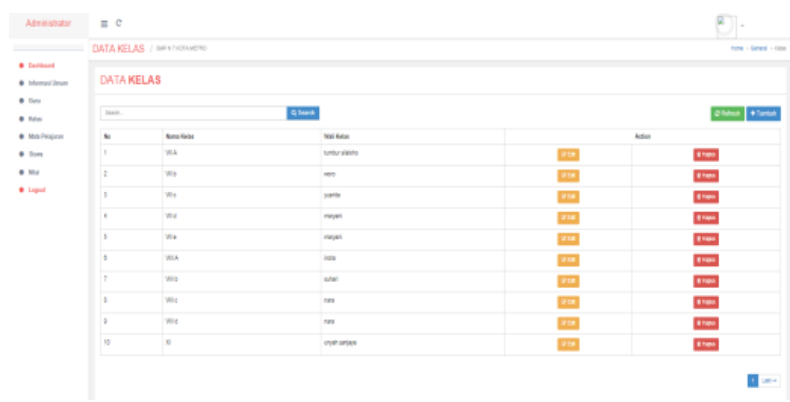

Tampilan From Input Data Mata Pelajaran

Tampilan ini berfungsi sebagai tampat untuk memasukan data mata pelajaran.

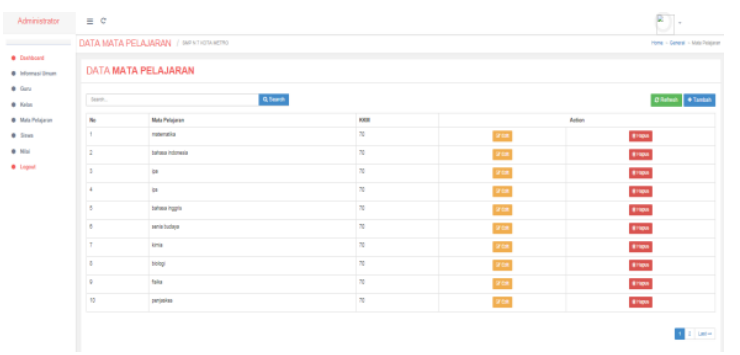

Tampilan From Input Data Siswa

Tampilan ini berfungsi sebagai tampat untuk memasukan data siswa.

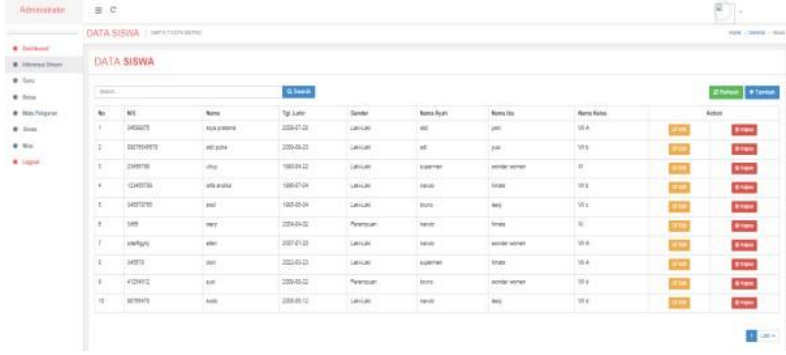

\section{KESIMPULAN}

Berdasarkan hasil penelitian dan pembahasan yang penulis lakukan dari hasil dan pembahasan yang telah dilakukan dalam pembuatan perancangan sistem informasi pengelolaan data nilai siswa berbasis web pada SMP Negei 7 Kota Metro maka dapat disimpulkan sebagai berikut :

1. Telah dikembangkan sistem akademik sekolah yang berbasis web untuk memudahkan staf tata usaha dan guru menginput hasil belajarnya dimana saja dan kapan saja.

2. Aplikasi dapat menyimpan data siswa, data guru, data kelas, data mata pelajaran dan data nilai siswa.

3. Aplikasi dapat menampilkan hasil belajar siswa dalam bentuk raport online. 


\section{DAFTAR PUSTAKA}

[1] Akhmad Lukman Wibowo (2013). Perancangan Sistem Informasi Pengolahan Nilai.Siswa Pada Smp N 4 Jepara Berbasis Intranet. Vol 2 No 1 Maret 2013 ISSN: 2302-1136 -

seruniid.unsa.ac.id.

[2] Bunafit Nugroho (2008). Latihan membuat aplikasi Web PHP dan MySQL dengan Dreamweaver. Yogyakarta : Penerbit Gramedia.

[3] Arief, M. Rudyanto. (2011). Pemrograman Web Dinamis menggunakan PHP dan MySQL. Yogyakarta : Andi Publisher.

[4] Eki Puspitasari,, Bambang Eka Purnama, Sukadi (2013), Sistem Informasi Pengolahan.

[5] Hidayatullah Priyanto, Khairil Jauhari (2015) Pemrograman Web (HTML/CSS/JavaScript/Power Designer/Xampp)Informatika Bandung.

[6] Sutabri, Tata (2012), Analisa Sistem Informasi, Edisi Satu. Yogyakarta; Andi.

[7]Susy Kusuma Wardani (2013). Sistem Informasi Pengolahan Data Nilai Siswa Berbasis Web pada Sekolah Menengah Atas (SMA) Muhammadiyah Pacitan. IJNS Volume 2 No 2 - April 2013 - ISSN: 2302-5700.

[8]Hartanto, Jogianto. 2005. Analisis dan Desain Yogyakakarta: ANDI. 